\title{
High-pressure co-gasification of coal with biomass and petroleum coke
}

\author{
J. Fermoso ${ }^{1}$, B. Arias ${ }^{1}$, M.G. Plaza ${ }^{1}$, C. Pevida ${ }^{1}$, F. Rubiera ${ }^{1}$, J.J. Pis ${ }^{1}$, F. García-Peña ${ }^{2}$, P. \\ Casero $^{2}$ \\ ${ }^{1}$ Instituto Nacional del Carbón, CSIC. Apartado 73. 33080 Oviedo. Spain \\ ${ }^{2}$ Elcogas S.A. C.T. GICC Puertollano. Carretera Calzada de Calatrava, km 27. \\ 13500 Puertollano, Ciudad Real. Spain
}

\begin{abstract}
The effect of the main operation variables (temperature, pressure and gasifying agent composition) on gas production and other process parameters, such as carbon conversion, cold gas efficiency and high heating value, during the steam-oxygen gasification of a bituminous coal were studied. It was observed that temperature and oxygen concentration were the most influential variables during the gasification process. In addition, co-gasification tests of binary blends of a bituminous coal with different types of biomass (up to $10 \%$ ) and petroleum coke (up to $60 \%$ ), as well as ternary blends of coal-petcoke-biomass (45-45-10\%) were conducted in order to study the effect of blending on gas production and carbon conversion.
\end{abstract}

\section{Keywords}

Hydrogen; Co-gasification; High pressure; Coal; Biomass

\section{Introduction}

Energy systems based on the use of hydrogen are considered a promising scenario in the long term. Some of the advantages of hydrogen energy include its low environmental impact and its attractive future applications in fuel cells technology for producing electricity [1]. $98 \%$ of the hydrogen produced nowadays comes from fossil fuels, mainly from natural gas reforming (approx. $50 \%$ ) [2]. However, due to the insecurity of its supply and the fluctuations in natural gas prices, it seems that, in the medium term, systems based on coal gasification may offer a possible alternative. Coal gasification is a well established technology for producing syngas $\left(\mathrm{CO}+\mathrm{H}_{2}\right)$, where hydrogen production can be increased by means of the water-gas shift reaction $\left(\mathrm{CO}+\mathrm{H}_{2} \mathrm{O}=\mathrm{CO}_{2}+\mathrm{H}_{2}\right)$. With this technology, a highly concentrated stream of hydrogen can be generated provided that $\mathrm{CO}_{2}$ capture is also undertaken. Some studies have 
shown that electricity generation based on the combination of hydrogen fuel cells and $\mathrm{CO}_{2}$ capture are less costly compared to post-combustion systems $[3,4]$.

One of the advantages of gasification technology is that energy sources (petcoke, biomass, wastes, etc.), other than coal can be used as feedstock. Petroleum coke is an important byproduct of petroleum refineries, and it is employed as feedstock in gasification systems, in combination with coal or separately, to produce a syngas that can be used to satisfy the increasing demand for hydrogen by refineries, and other applications [5]. Moreover, the cogasification of biomass with coal, could contribute to the reduction of the fossil fuels dependency and $\mathrm{CO}_{2}$ emissions, as biomass is known to be neutral as regards $\mathrm{CO}_{2}$ emissions [6]. During co-gasification coal, biomass and other wastes are put together and converted into a gaseous product stream that can be used to produce electricity, hydrogen, chemicals and liquid transportation fuels. Biomass and wastes are generally more difficult to process than coal, due to their heterogeneity which produces fluctuations in quality, availability and composition. Therefore, the use of coal with biomass and wastes can provide stable gasification conditions and could prevent problems due to wastes seasonal shortness [7].

On the other hand, biomass has a lower ash and sulphur content than coal, a higher volatile matter yield and fixed carbon with higher reactivity. Therefore, blending low quality coal with biomass and wastes could be attractive from an economical, environmental and social points of view in order to make use of possible synergistic effects via the production of fuel gas [8]. Additionally, biomass and coal are considered as potential feedstocks for the supply of syngas $\left(\mathrm{CO}\right.$ and $\left.\mathrm{H}_{2}\right)$ used in the synthesis of liquid fuels by gasification. In recent years, the advantages of the cogasification of woody biomass and coal have been reported by several researchers, including the reduction in the production of tar when coal is cogasified with biomass, which can produce large amounts of tar when gasified alone [6, 9-11].

Currently, cogasification of coal and biomass is conducted at IGCC electricity generating power stations such as the Willem-Alexander power station in Buggenum (Netherlands), where residual wastes from the agricultural sector, such as sawdust, grape and sunflower seeds, and peanut shells are cogasified with coal. Similarly, at ELCOGAS the world's largest IGCC facility using coal and petcoke as feedstock, located in Puertollano (Spain), there is an ongoing project aimed at evaluating the effects of adding small percentages of biomass, up to a maximum amount of $10 \%$, on the performance of the plant [12]. 
Within this frame, the effects of co-processing biomass and waste with coal cannot be easily derived from tests at large scale or even at pilot scale, where it is difficult to cover a wide range of conditions, repeat experiments and verify reported trends. Therefore, the results achieved at bench-scale, such as the ones reported in the present paper are aimed at providing overall trends and to render a framework within which pilot plant operating parameters may be selected.

The objective of this work was to study the effect of several operation variables (temperature, pressure and gasifying agent composition), on gas production, carbon conversion, cold gas efficiency and high heating value, during the steam-oxygen gasification of a bituminous coal. The effect of blending this coal with petcoke and biomass on gas composition was also studied.

\section{Experimental}

In this work, a bituminous coal (PT), a petcoke (PC), and three types of biomass, almond shells (AS), olive stones (OS) and eucalyptus (EB) were used. The samples were ground and sieved to obtain a fraction with a particle size of 75-150 $\mu \mathrm{m}$. The proximate and ultimate analyses and the high heating value of the samples are presented in Table 1.

A stainless steel tubular reactor (13 mm internal diameter, $305 \mathrm{~mm}$ height) with a porous plate was used for the gasification tests. This reactor is able to work at a maximum pressure of 2 $\mathrm{MPa}$ at $1273 \mathrm{~K}$. Figure 1 shows a flow diagram of the system. Solids are fed continuously into the system from a pressurized hopper. The mass flow rate of the solids is controlled using a pneumatically actuated valve.

The reactor temperature is controlled by means of a thermocouple connected to a temperature controller and data recorder. The thermocouple is in contact with the sample bed. The pressure is measured by a pressure transducer and automatically controlled by a micro-valve. The gasification tests were carried out isothermally at temperatures between 1123 and $1273 \mathrm{~K}$, using a mixture of steam $(40-85$ vol. \%) and oxygen $(2-15$ vol. \%), carried in an inert flow of $\mathrm{N}_{2}$, at a total flow rate of $200 \mathrm{Ncm}^{3} \mathrm{~min}^{-1}$. The experiments were performed at pressures ranging from 0.5 to $2 \mathrm{MPa}$. The tars formed during the process and the excess steam were separated from the gas flow by means of a thermoelectric cooler. The gas composition of the dried gases $\left(\mathrm{H}_{2}, \mathrm{O}_{2}, \mathrm{~N}_{2}, \mathrm{CO}, \mathrm{CH}_{4}\right.$ and $\left.\mathrm{CO}_{2}\right)$ was analysed on-line, using a dual channel micro-GC Varian CP-4900 fitted with a thermal conductive detector (TCD). The micro-GC was equipped with a molecular sieve, Molsieve $5 \AA$, and a HayeSep A, columns; helium was 
used as carrier gas. The system was calibrated employing a standard gas mixture at periodic intervals. The amount of gas generated during the experiments was calculated from a nitrogen balance, since the amount of nitrogen fed in and the composition of the nitrogen evolved are known.

\section{Results and discussion}

\subsection{Effect of operation variables}

The final gas composition of the gasification process is the result of the combination of a series of complex and competing reactions:

Oxidation

$$
\begin{aligned}
& \mathrm{C}+\mathrm{O}_{2} \rightarrow \mathrm{CO}_{2} \\
& \mathrm{C}+\frac{1}{2} \mathrm{O}_{2} \rightarrow \mathrm{CO}
\end{aligned}
$$

Boudouard:

$$
\mathrm{C}+\mathrm{CO}_{2} \rightarrow 2 \mathrm{CO}
$$

Water gas

$$
\begin{array}{ll}
\multicolumn{1}{l}{\text { Primary: }} & \mathrm{C}+\mathrm{H}_{2} \mathrm{O} \rightarrow \mathrm{CO}+\mathrm{H}_{2} \\
\multicolumn{1}{c}{\text { Secondary: }} & \mathrm{C}+2 \mathrm{H}_{2} \mathrm{O} \rightarrow \mathrm{CO}_{2}+2 \mathrm{H}_{2} \\
\text { Methanation: } & \mathrm{C}+2 \mathrm{H}_{2} \rightarrow \mathrm{CH}_{4} \\
\text { Water gas shift: } & \mathrm{CO}+\mathrm{H}_{2} \mathrm{O} \rightarrow \mathrm{CO}_{2}+\mathrm{H}_{2} \\
\text { Steam reforming: } & \mathrm{CH}_{4}+\mathrm{H}_{2} \mathrm{O} \rightarrow \mathrm{CO}+3 \mathrm{H}_{2} \\
\text { Dry reforming: } & \mathrm{CH}_{4}+\mathrm{CO}_{2} \rightarrow 2 \mathrm{CO}+2 \mathrm{H}_{2}
\end{array}
$$

The effect of the main operation variables (temperature, pressure and composition of the gasifying agent) during the steam gasification of a bituminous coal (PT) on gas production was studied. In addition, other important parameters such as carbon conversion, $X(\%)$, gas yield, $Y\left(\mathrm{Nm}^{3} \mathrm{~kg}^{-1}\right)$, gas high heating value, $G H H V\left(\mathrm{~kJ} \mathrm{Nm}^{-3}\right)$, and cold gas efficiency, $\eta(\%)$, were calculated.

In this work, the carbon conversion, $X$, was defined as the total carbon contained in the gas produced $\left(\mathrm{CH}_{4}, \mathrm{CO}\right.$ and $\left.\mathrm{CO}_{2}\right)$ with respect to the total carbon contained in the sample fed in. 
The gas yield, $Y$, was calculated as the outgoing dry gas flow rate per mass flow rate of dry fuel. The gas high heating value, $G H H V$, was defined as the gross calorific value of dry gas on a volumetric basis. Finally, the cold gas efficiency, $\eta$, was defined as the ratio between the energy content of the gas and the energy contained in the solid fuel.

\subsubsection{Reaction temperature}

Reaction temperature is one of the most important operating parameters affecting the performance of gasification, due to the balance between endothermic and exothermic reactions involved $[7,13]$. To study the effect of temperature, the reactive gas composition was set at $5 \% \mathrm{O}_{2}$ and $70 \% \mathrm{H}_{2} \mathrm{O}$, according to a previous optimization procedure aimed at maximising the production of $\mathrm{H}_{2}+\mathrm{CO}$ and increasing the carbon conversion $[14,15]$. The pressure of the system was fixed at $1 \mathrm{MPa}$. Figure 2 shows the influence of the bed temperature on gas production. An increase in the temperature clearly favours the formation of $\mathrm{H}_{2}$ and $\mathrm{CO}$, since the endothermic gasification reactions (Eqs. 3-5) are enhanced. However, at low temperatures carbon oxidation reactions (Eqs. 1 and 2) are more significant than carbon gasification, since the former are exothermic, and $\mathrm{CO}_{2}$ production is more favoured. As the reaction temperature increases, carbon tends to react with $\mathrm{CO}_{2}$, through the Boudouard reaction (Eq. 3), displacing the equilibrium to $\mathrm{CO}$ formation [16], as can be seen in the evolution of the $\mathrm{CO} / \mathrm{CO}_{2}$ ratio (Table 2). The increase in $\mathrm{CO}$ affects the $\mathrm{H}_{2} / \mathrm{CO}$ ratio which falls from 4.4 to 2.1 as the temperature increases from 1123 to $1273 \mathrm{~K}$. The production of $\mathrm{CH}_{4}$ remains almost constant and is not affected by the variation in reaction temperature. This indicates that the methanation reaction (Eq. 6), does not take place to any significant extent and $\mathrm{CH}_{4}$ is produced mainly during the pyrolysis step [14].

A rise in the reaction temperature produces an increase in carbon conversion through oxidation and gasification reactions (Eqs. 1-6).This originates an increase in gas yield and its HHV, which leads to a higher cold gas efficiency. These results agree with the studies published by other authors who employed different types of gasifiers such as pressurized spouted bed and fluidised bed reactors [13, 17-20]. The carbon conversion undergoes a considerable increase ( $28 \%$ ) between 1223 and $1273 \mathrm{~K}$; cold gas efficiency also increases reaching a value of $94.4 \%$ at $1273 \mathrm{~K}$ (see Table 2).

To evaluate the differences between the experimentally obtained gas concentrations and those corresponding to the equilibrium, a gasification reaction equilibrium model based on the minimization of the total Gibbs free energy was used [21]. It was observed that for all the 
temperatures tested in the present work, the experimental $\mathrm{H}_{2}$ and $\mathrm{CO}$ concentrations were lower than the predicted values, while $\mathrm{CO}_{2}$ concentrations were higher than the theoretical results. However, the differences between the experimental and equilibrium values diminished as the temperature increased. For instance at $1123 \mathrm{~K}$ the experimental values for the concentrations of $\mathrm{H}_{2}$ and $\mathrm{CO}$ were $25.7 \%$ and $5.8 \%$, respectively, while those of the equilibrium were $43.8 \%$ and $18.3 \%$, respectively. However, at $1273 \mathrm{~K}$ the experimental values were $34.6 \%\left(\mathrm{H}_{2}\right)$ and $16.6 \%(\mathrm{CO})$, while the equilibrium values were $42 \%\left(\mathrm{H}_{2}\right)$ and $18.8 \%(\mathrm{CO})$. Among the reasons that can cause the difference between the equilibrium and the experimental results is the carbon conversion, as it has been stated by other researchers [7, 22, 23]. Higher temperatures improve the extent of gasification reactions, and therefore, result in gas composition closer to equilibrium. In this way a lower difference between experimental concentrations and theoretical ones is attained.

\subsubsection{Gasifying agent composition}

The composition of the gasifying agents determines that of the gas produced and, in turn, the efficiency of the process. In this work, this parameter was studied by varying the oxygen and steam concentrations in the reactive gas, and expressing the results as a function of the $\mathrm{O} / \mathrm{C}$ and $\mathrm{H}_{2} \mathrm{O} / \mathrm{C}$ ratios. Figure 3 shows the production of the main gases during the gasification of coal PT $(1223 \mathrm{~K}$ and $1 \mathrm{MPa})$ using a steam concentration of $70 \%$ vol. $\left(\mathrm{H}_{2} \mathrm{O} / \mathrm{C}=2.86\right)$, as a function of the $\mathrm{O} / \mathrm{C}$ ratio. As a result of the increase in oxygen content in the gasifying agent, $\mathrm{CO}_{2}$ production increases sharply, mainly due to coal oxidation. The significant decrease in $\mathrm{H}_{2}$ production is a consequence of oxygen being much more reactive to carbon than steam [24]. What is more, some of the $\mathrm{H}_{2}$ produced might have burned up if oxygen were present. For this reason, although an increase in the $\mathrm{O} / \mathrm{C}$ ratio produces an increase in the conversion of carbon, there is a concomitant decrease in cold gas efficiency due to the lower HHV of the gas produced (see Table 3) [7, 25]. In the results shown in Figure 3 there is a slight reduction in $\mathrm{CO}$ production, while $\mathrm{CH}_{4}$ remains practically unaltered, in accordance with the results obtained by other authors employing other types of reactor [7, 13].

The effect of varying the steam concentration $\left(\mathrm{H}_{2} \mathrm{O} / \mathrm{C}\right.$ ratio), employing an oxygen concentration of $5 \%$ vol. $(\mathrm{O} / \mathrm{C}=0.36)$, on gas production is shown in Figure $4(1223 \mathrm{~K}, 1$ MPa). Carbon steam gasification (Eq. 5) is enhanced when the $\mathrm{H}_{2} \mathrm{O} / \mathrm{C}$ ratio increases, leading to a slight increase in $\mathrm{H}_{2}$ and $\mathrm{CO}_{2}$ production, while $\mathrm{CO}$ production remains almost constant. This suggests that the secondary steam gasification reaction is favoured to the detriment of the primary one at high steam concentrations. At high values of $\mathrm{H}_{2} \mathrm{O} / \mathrm{C}$ ratio, $\mathrm{H}_{2}$ production 
decreases slightly, which could be due to the formation of $\mathrm{CH}_{4}$ (Eq. 6). The theoretical gas composition, calculated from the equilibrium model, shows a trend similar to the experimental values. This result confirms that the increase in steam in the gasifying medium favours the secondary steam gasification reaction (Eq. 5) to the detriment of the primary reaction (Eq. 4).

As can be seen in Table 3, the $\mathrm{H}_{2} / \mathrm{CO}$ ratio increases slightly as the steam content rises in the gasifying agent. However, this parameter clearly decreases when there is a rise in the concentration of oxygen in the reactive gas. What is more, carbon conversion is affected more by the variation in $\mathrm{O} / \mathrm{C}$ ratio than by the $\mathrm{H}_{2} \mathrm{O} / \mathrm{C}$ ratio, as can be observed in Table 3 . These findings could be useful when deciding the composition of the gasifying agent depending on the application desired of the gas produced (electricity, hydrogen production, liquid fuels synthesis through Fischer-Tropsch method, etc.).

\subsubsection{Reaction pressure}

The effect of reaction pressure on gas production during the gasification of coal PT was studied and the results are presented in Figure $5\left(1223 \mathrm{~K}, 5 \% \mathrm{O}_{2}, 55 \% \mathrm{H}_{2} \mathrm{O}\right)$. In this figure it can be observed that, in the range of pressures studied in this work, pressure does not have a significant effect on gas production. However, an increase in pressure was observed to produce a slight increase in $\mathrm{CH}_{4}$ and $\mathrm{CO}_{2}$ to the detriment of $\mathrm{H}_{2}$ and $\mathrm{CO}$ [19], as the increase in pressure shifts the equilibrium to shift to the side with the fewer moles of gas (Eqs. 8 and 9). The same tendencies were observed when the equilibrium gas composition was calculated by varying the total pressure. It can be seen in Table 4 that only the high heating value of the raw gas is reduced slightly due to the change in pressure.

\subsection{Effect of blending fuels}

The effect of blending coal with biomass and petcoke was studied in order to determine the possible presence of synergetic phenomena. Gasification tests of binary blends of coal PT combined with different biomass samples (AS, EB and OS), and with petcoke (PC), as well as ternary blends (PT-PC-Biomass) were carried out. For this purpose, the feed mass flow rate was set to maintain the values of the $\mathrm{O} / \mathrm{C}$ and $\mathrm{H}_{2} \mathrm{O} / \mathrm{C}$ ratios constant. The experimental conditions were fixed at $5 \% \mathrm{O}_{2}$ and $55 \%$ steam, with a pressure of $1.5 \mathrm{MPa}$ and a temperature of $1273 \mathrm{~K}$. The experimental error margin was evaluated by calculating the errors produced in the gas composition from repeating an experiment several times on different 
days. The values obtained, expressed in mol of gas per kilo of sample on a dry ash free basis, were lower than 2 for $\mathrm{H}_{2}$, and lower than 1 for $\mathrm{CO}$ and $\mathrm{CO}_{2}$.

Figure 6 shows the main gases production during the gasification of the PT-PC blends. There is a positive deviation from the linear additive rule in the case of $\mathrm{H}_{2}$ and $\mathrm{CO}$ production, whilst the amount of $\mathrm{CO}_{2}$ and $\mathrm{CH}_{4}$ can be calculated from the production of the individual blend components and proportions. These results show a positive synergetic effect between the components of the blend. This type of behaviour can also be observed in the results shown in Figure 7, where carbon conversion, cold gas efficiency and high heating values are plotted as a function of the percentage of the PC in the blends. The carbon conversion decreases with the increase in petcoke content due to its lower reactivity compared to coal [26]. However, in all cases a clearly positive effect was attained when coal PT was blended with petcoke PC.

In the case of the blends of PT with different biomasses (Figure 8) the production of $\mathrm{H}_{2}$, and especially that of $\mathrm{CO}$, increased with additions of up to $10 \%$ biomass. The increase in $\mathrm{CO}_{2}$ was more evident when coal was blended with EB. This behaviour in gas production was reflected in the $\mathrm{H}_{2} / \mathrm{CO}$ ratio, which decreased slightly for all the blends (see Table 5), in agreement with the results found by other authors [11, 27]. In general, other process parameters such as carbon conversion and cold gas efficiency clearly improved when coal PT was gasified with biomass due to the high carbon conversion to gas.

Finally, ternary blends of PT, PC and the three biomasses were gasified to determine the presence of possible interactions between the three fuels due to the positive effects observed when PT-Biomass and PT-PC were blended separately. Figure 9 shows the gas production during the gasification experiments of the PT-PC-Biomass ternary blends (45-45-10\%). In this figure it can be seen that when biomass was used with blend PT-PC, $\mathrm{H}_{2}$ production remained almost constant. However, a slight decrease in CO production and a slight increase in $\mathrm{CO}_{2}$ production were attained in all cases. This is reflected in the evolution of the $\mathrm{H}_{2} / \mathrm{CO}$ and $\mathrm{CO} / \mathrm{CO}_{2}$ ratios presented in Table 6 . This table shows an improvement in the efficiency of the process due to the increase in carbon conversion and cold gas efficiency. 


\section{Conclusions}

The effect of temperature, pressure and gasifying agent concentration on gas production and other process parameters such as carbon conversion, cold gas efficiency and high heating value was studied. It was found that temperature and oxygen concentration had the greatest influence on the final products, which were practically unaffected by changes in reaction pressure. An increase in the temperature of reaction led to a significant increase in $\mathrm{H}_{2}$ and $\mathrm{CO}$ production. With respect to the $\mathrm{O} / \mathrm{C}$ ratio, it was observed that the production of $\mathrm{CO}_{2}$ and $\mathrm{CO}$ increased to the detriment of $\mathrm{H}_{2}$, which decreased sharply. When the concentration of steam in the reactive gas was increased, an increase in $\mathrm{H}_{2}$ production was observed, whereas $\mathrm{CO}$ production diminished slightly. A positive synergistic effect was observed for blends of coal with petcoke, and an increase in the production of $\mathrm{H}_{2}$ and $\mathrm{CO}$ was obtained. Furthermore, the addition of a small amount of biomass (up to $10 \%$ ), led to an increase in $\mathrm{H}_{2}$ and $\mathrm{CO}$ production in all the biomasses used. Finally, blending biomass with PT-PC blends did not produce any significant change in $\mathrm{H}_{2}$ production, although slight variations were observed in the production of $\mathrm{CO}$ and $\mathrm{CO}_{2}$.

\section{Acknowledgements}

This work was carried out with financial support from the Spanish CDTI (Project CENIT PiIBE) and ELCOGAS, S.A. J.F. and M.G.P. acknowledge funding from the PCTI Asturias, and CSIC JAE Program, respectively.

\section{References}

[1] A. Midilli, M. Ay, I. Dincer, M. A. Rosen. On hydrogen and hydrogen energy strategies: I: current status and needs. Renewable and Sustainable Energy Reviews 9 (2005) 255-271.

[2] S. Dunn. Hydrogen futures: toward a sustainable energy system. International Journal of Hydrogen Energy 27 (2002) 235-264.

[3] K. Damen, M. van Troost, A. Faaij, W. Turkenburg. A comparison of electricity and hydrogen production systems with $\mathrm{CO}_{2}$ capture and storage. Part A: Review and selection of promising conversion and capture technologies. Progress in Energy and Combustion Science 32 (2006) 215-246. 
[4] K. Damen, M. van Troost, A. Faaij, W. Turkenburg. A comparison of electricity and hydrogen production systems with $\mathrm{CO}_{2}$ capture and storage - Part B: Chain analysis of promising CCS options. Progress in Energy and Combustion Science 33 (2007) 580-609.

[5] S. Nagpal, T. K. Sarkar, P. K. Sen. Simulation of petcoke gasification in slagging moving bed reactors. Fuel Processing Technology 86 (2005) 617-640.

[6] T. R. McLendon, A. P. Lui, R. L. Pineault, S. K. Beer, S. W. Richardson. High-pressure co-gasification of coal and biomass in a fluidized bed. Biomass and Bioenergy 26 (2004) 377388.

[7] F. Pinto, C. Franco, R. Neto André, C. Tavares, M. Dias, I. Gulyurtlu, I. Cabrita. Effect of experimental conditions on co-gasification of coal, biomass and plastics wastes with air/steam mixtures in a fluidized bed system. Fuel 82 (2003) 1967-1976.

[8] Y.G. Pan, E. Velo, X. Roca, J.J. Manyà, L. Puigjaner. Fluidized-bed co-gasification of residual biomass/poor coal blends for fuel gas production. Fuel 79 (2000) 1317-1326

[9] C.R. Brown, Q. Liu, G. Norton. Catalytic effects observed during the co-gasification of coal and switchgrass. Biomass and Bioenergy 18 (2000) 499-506.

[10] T. Chmielniak, M. Sciazko. Co-gasification of biomass and coal for methanol synthesis. Applied Energy 74 (2003) 393-403.

[11] K. Kumabe, T. Hanaoka, S. Fujimoto, T. Minowa, K. Sakanishi. Co-gasification of woody biomass and coal with air and steam. Fuel 86 (2007) 684-689.

[12] P. Casero. Puertollano IGCC power plant. Operational experience and current developments. International Freiberg Conference on IGCC and XtL Technologies, May 2007, Freiberg, Germany.

[13] Y. J. Kim, S. H. Lee, S. D. Kim. Coal gasification characteristics in a downer reactor. Fuel 80 (2001) 1915-1922.

[14] J. Fermoso, B. Arias, C. Pevida, M. G. Plaza, F. Rubiera, J. J. Pis. Hydrogen production from the co-utilisation of coal and biomass. In: Proceedings International Conference on Coal Science and Technology, Nottingham, UK, 28-31 August, 2007. 
[15] J. Fermoso. MSc Thesis. Co-gasification of coal and biomass for hydrogen production. University of Oviedo. June 2007.

[16] L. Bassi. Coal gasification and combustion process proven and new technologies for a clean use in advanced power plant. Flowers (1997) pp 429-436.

[17] R. Xiao, M. Zhang, B. Jin, Y. Huang. High-temperature air/steam-blown gasification of coal in a pressurized spout-fluid bed. Energy \& Fuels 20 (2006) 715-720.

[18] R. Xiao, M. Zhang, B. Jin, Y. Xiaong, H. Zhou, Y. Duan, Z. Zhong, X. Chen, Y. Huang. Air blown partial gasification of coal in a pilot plant pressurized spout-fluid bed reactor. Fuel 86 (2007) 1631-1640.

[19] T. A. Sue-A-Quan, A. P. Watkinson, R. P. Gaikwad, C. J. Lim, B. R. Ferris. Steam gasification in a pressurized spouted bed reactor. Fuel Processing Technology 27 (1991) 6781.

[20] A. Ocampo, E. Arenas, F. Chejne, J. Espinel, C. Londoño, J. Aguirre, J. D. Perez. An experimental study on gasification of Colombian coal in fluidised bed. Fuel 82 (2003) 161164.

[21] C. Morley. GASEQ: A chemical equilibrium program for Windows. Ver 0.79, 2005.

[22] S. Jarungthammachote, A. Dutta. Equilibrium modeling of gasification: Gibbs free energy minimization approach and its application to spouted bed and spout-fluid bed gasifiers. Energy Conversion and Management, 49 (2008) 1345-1356.

[23] Y. Wang, C.M. Kinoshita. Experimental analysis of biomass gasification with steam and oxygen. Solar Energy 49 (1992) 153-158.

[24] G-S. Liu, S. Niksa. Coal conversion submodels for design applications at elevated pressures. Part II. Char gasification. Progress in Energy and Combustion Science 30 (2004) $679-717$

[25] J. Huang, Y. Fang, H. Chen, Y. Wang. Coal gasification characteristic in a pressurized fluidized bed. Energy \& Fuels 17 (2003) 1474-1479. 
[26] J. Fermoso, B. Arias, C. Pevida, M. G. Plaza, F. Rubiera, J. J. Pis. Kinetic models comparison for steam gasification of different nature fuel chars. Journal of Thermal Analysis and Calorimetry 91 (2008) 779-786.

[27] R. Neto André, F. Pinto, C. Franco, M. Dias, I. Gulyurtlu, M. A. A. Matos, I. Cabrita. Fluidised bed co-gasification of coal and olive oil industry wastes. Fuel 84 (2005) 1635-1644. 
Table 1. Proximate and ultimate analyses and high heating values of the samples

\begin{tabular}{|c|c|c|c|c|c|c|c|c|}
\hline \multirow[t]{2}{*}{ Sample } & \multicolumn{2}{|c|}{ Proximate Analysis (wt.\%, db) } & \multicolumn{5}{|c|}{ Ultimate Analysis (wt.\%, daf) } & \multirow{2}{*}{$\begin{array}{c}\text { HHV } \\
\left(\mathrm{MJ} \mathrm{kg}^{-1}\right)\end{array}$} \\
\hline & Ash & V.M. & $\mathrm{C}$ & $\mathrm{H}$ & $\mathrm{N}$ & $\mathrm{S}$ & $\mathrm{O}^{*}$ & \\
\hline PT & 37.0 & 24.3 & 75.7 & 5.3 & 1.4 & 1.6 & 16.0 & 18.7 \\
\hline $\mathrm{PC}$ & 0.3 & 9.6 & 87.6 & 3.8 & 1.5 & 6.2 & 0.9 & 35.0 \\
\hline $\mathrm{AS}$ & 1.2 & 79.3 & 49.8 & 6.1 & 0.2 & 0.0 & 43.9 & 19.7 \\
\hline OS & 0.8 & 83.8 & 52.0 & 6.2 & 0.1 & 0.0 & 41.7 & 20.3 \\
\hline EB & 0.7 & 83.6 & 50.6 & 6.4 & 0.1 & 0.0 & 42.9 & 19.4 \\
\hline
\end{tabular}

dry basis (db); dry ash free basis (daf); ${ }^{*}$ calculated by difference

Table 2. Gasification parameters of coal PT at different temperatures $\left(1 \mathrm{MPa}, 5 \% \mathrm{O}_{2}, 70 \%\right.$ $\mathrm{H}_{2} \mathrm{O}$ )

\begin{tabular}{ccccc}
\hline & \multicolumn{4}{c}{$\mathrm{T}(\mathrm{K})$} \\
\cline { 2 - 5 } & 1123 & 1173 & 1223 & 1273 \\
\hline $\mathrm{H}_{2} / \mathrm{CO}$ & 4.4 & 3.0 & 2.3 & 2.1 \\
$\mathrm{CO} / \mathrm{CO}_{2}$ & 0.3 & 0.6 & 0.9 & 1.1 \\
$\mathrm{GHHV}\left(\mathrm{kJ} \mathrm{Nm}^{-3}\right)$ & 5402 & 6517 & 7059 & 7586 \\
$\mathrm{Y}\left(\mathrm{Nm}^{3} \mathrm{~kg}^{-1}\right)$ & 1.3 & 1.5 & 1.7 & 2.3 \\
$\eta(\%)$ & 38.0 & 50.6 & 64.3 & 94.4 \\
$\mathrm{X}(\%)$ & 39.7 & 48.9 & 61.4 & 89.4 \\
\hline
\end{tabular}


Table 3. Gasification parameters of coal $\mathrm{PT}$ at different $\mathrm{O} / \mathrm{C}$ and $\mathrm{H}_{2} \mathrm{O} / \mathrm{C}$ ratios $(1 \mathrm{MPa}, 1223$ K)

\begin{tabular}{ccccc|cccc}
\hline & \multicolumn{4}{c|}{$\mathrm{O} / \mathrm{C}$} & \multicolumn{4}{c}{$\mathrm{H}_{2} \mathrm{O} / \mathrm{C}$} \\
\cline { 2 - 9 } & 0.14 & 0.36 & 0.75 & 1.27 & 1.47 & 2.07 & 2.86 & 4.03 \\
\hline $\mathrm{H}_{2} / \mathrm{CO}$ & 2.8 & 2.3 & 2.0 & 1.7 & 2.0 & 2.2 & 2.3 & 2.3 \\
$\mathrm{CO} / \mathrm{CO}_{2}$ & 1.0 & 0.9 & 0.7 & 0.6 & 1.2 & 1.0 & 0.9 & 0.8 \\
$\mathrm{GHHV}\left(\mathrm{kJ} \mathrm{Nm}^{-3}\right)$ & 7182 & 7059 & 6793 & 6448 & 4854 & 5987 & 7059 & 8588 \\
$\mathrm{Y}\left(\mathrm{Nm}^{3} \mathrm{~kg}^{-1}\right)$ & 1.8 & 1.7 & 1.6 & 1.7 & 2.1 & 1.9 & 1.7 & 1.4 \\
$\eta(\%)$ & 68.8 & 64.3 & 58.3 & 57.0 & 55.7 & 61.8 & 64.3 & 63.8 \\
$\mathrm{X}(\%)$ & 57.2 & 61.4 & 69.6 & 86.2 & 52.7 & 58.2 & 61.4 & 63.2 \\
\hline
\end{tabular}

Table 4. Gasification parameters of coal PT at different pressures $\left(1223 \mathrm{~K}, 5 \% \mathrm{O}_{2}, 55 \%\right.$ $\mathrm{H}_{2} \mathrm{O}$ )

\begin{tabular}{ccccc}
\hline & \multicolumn{4}{c}{$\mathrm{P}(\mathrm{MPa})$} \\
\cline { 2 - 5 } & 0.5 & 1.0 & 1.5 & 2.0 \\
\hline $\mathrm{H}_{2} / \mathrm{CO}$ & 2.2 & 2.2 & 2.3 & 2.3 \\
$\mathrm{CO} / \mathrm{CO}_{2}$ & 1.2 & 1.0 & 1.0 & 1.0 \\
$\mathrm{GHHV}\left(\mathrm{kJ} \mathrm{Nm}^{-3}\right)$ & 6384 & 5987 & 6223 & 6073 \\
$\mathrm{Y}\left(\mathrm{Nm}^{3} \mathrm{~kg}^{-1}\right)$ & 2.0 & 1.9 & 2.1 & 2.1 \\
$\eta(\%)$ & 67.5 & 61.8 & 69.0 & 67.3 \\
$\mathrm{X}(\%)$ & 60.9 & 58.2 & 62.7 & 61.4 \\
\hline
\end{tabular}


Table 5. Gasification parameters of binary blends of coal PT with biomass (1.5 MPa, $1273 \mathrm{~K}$, $\left.5 \% \mathrm{O}_{2}, 55 \% \mathrm{H}_{2} \mathrm{O}\right)$

\begin{tabular}{|c|c|cc|cc|cc|}
\hline & & \multicolumn{2}{|c|}{$\mathrm{AS}$} & \multicolumn{2}{c|}{ EB } & \multicolumn{2}{c|}{ OS } \\
\cline { 2 - 8 }$\%$ Biomass & 0 & 5 & 10 & 5 & 10 & 5 & 10 \\
\hline $\mathrm{H}_{2} / \mathrm{CO}$ & 2.3 & 2.0 & 2.1 & 2.0 & 2.2 & 2.0 & 2.2 \\
$\mathrm{CO} / \mathrm{CO}_{2}$ & 1.0 & 1.2 & 1.2 & 1.1 & 1.0 & 1.2 & 1.1 \\
$\mathrm{GHHV}\left(\mathrm{kJ} \mathrm{Nm}^{-3}\right)$ & 6223 & 6363 & 6276 & 6234 & 5882 & 6579 & 6575 \\
$\mathrm{Y}\left(\mathrm{Nm}^{3} \mathrm{~kg}^{-1}\right)$ & 2.1 & 2.2 & 2.3 & 2.4 & 2.6 & 2.3 & 2.3 \\
$\eta(\%)$ & 69.0 & 75.2 & 77.7 & 78.2 & 80.2 & 80.2 & 78.9 \\
$\mathrm{X}(\%)$ & 62.7 & 69.2 & 71.0 & 73.9 & 74.4 & 72.6 & 70.1 \\
\hline
\end{tabular}

Table 6. Gasification parameters of ternary blends of PT-PC (45-45\%) with biomass (10\%) (1.5 MPa, $\left.1273 \mathrm{~K}, 5 \% \mathrm{O}_{2}, 55 \% \mathrm{H}_{2} \mathrm{O}\right)$.

\begin{tabular}{|c|c|c|c|c|}
\hline & & AS & EB & OS \\
\cline { 2 - 5 }$\%$ Biomass & 0 & 10 & 10 & 10 \\
\hline $\mathrm{H}_{2} / \mathrm{CO}$ & 1.6 & 1.8 & 1.8 & 1.8 \\
$\mathrm{CO} / \mathrm{CO}_{2}$ & 1.9 & 1.6 & 1.5 & 1.6 \\
$\mathrm{GHHV}\left(\mathrm{kJ} \mathrm{Nm}^{-3}\right)$ & 7132 & 6779 & 6607 & 6626 \\
$\mathrm{Y}\left(\mathrm{Nm}^{3} \mathrm{~kg}^{-1}\right)$ & 3.7 & 3.9 & 4.0 & 4.1 \\
$\eta(\%)$ & 97.4 & 101.4 & 101.3 & 102.5 \\
$\mathrm{X}(\%)$ & 91.1 & 94.8 & 97.5 & 94.7 \\
\hline
\end{tabular}




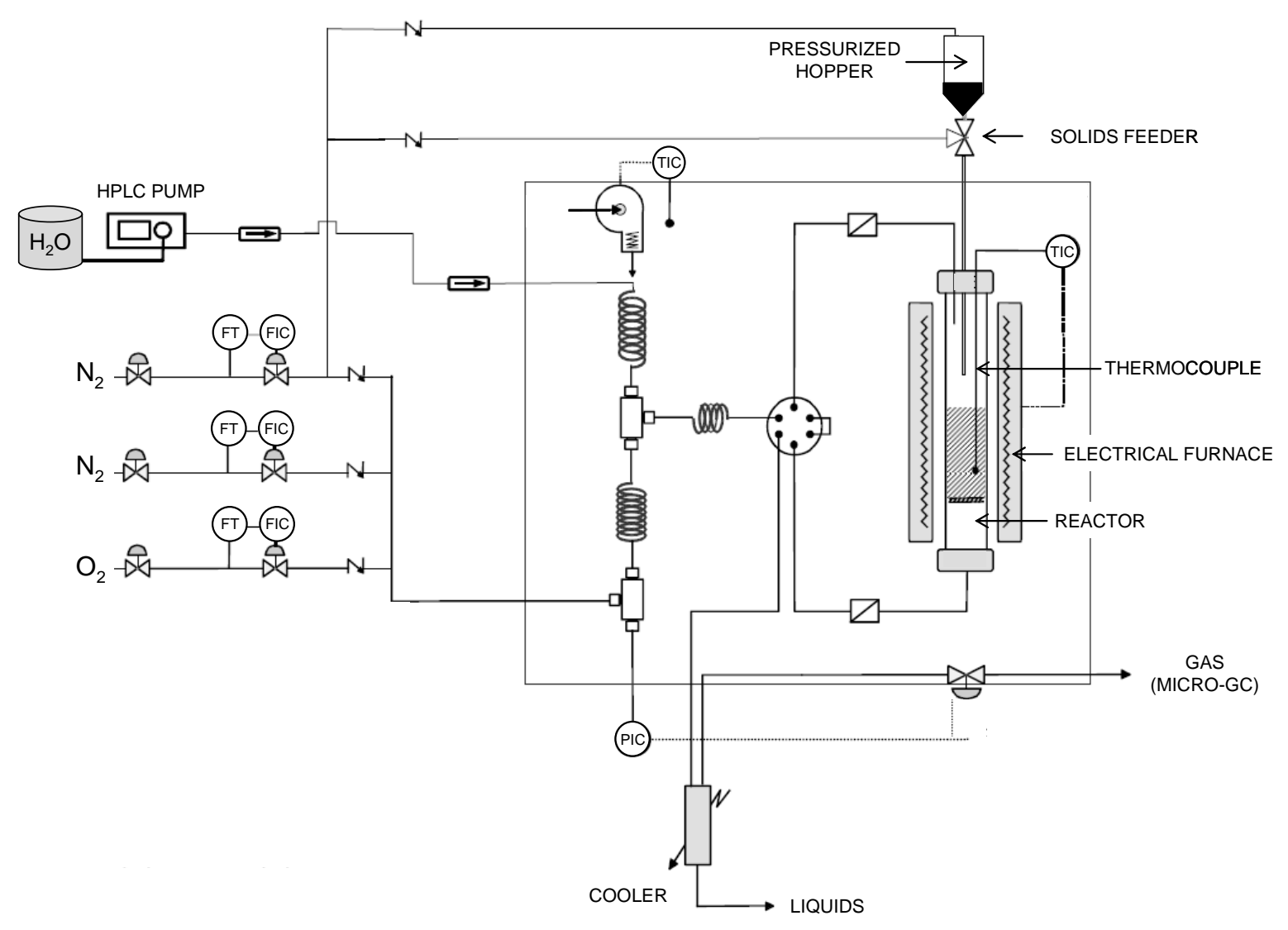

Figure 1. Flow diagram of the experimental device. 


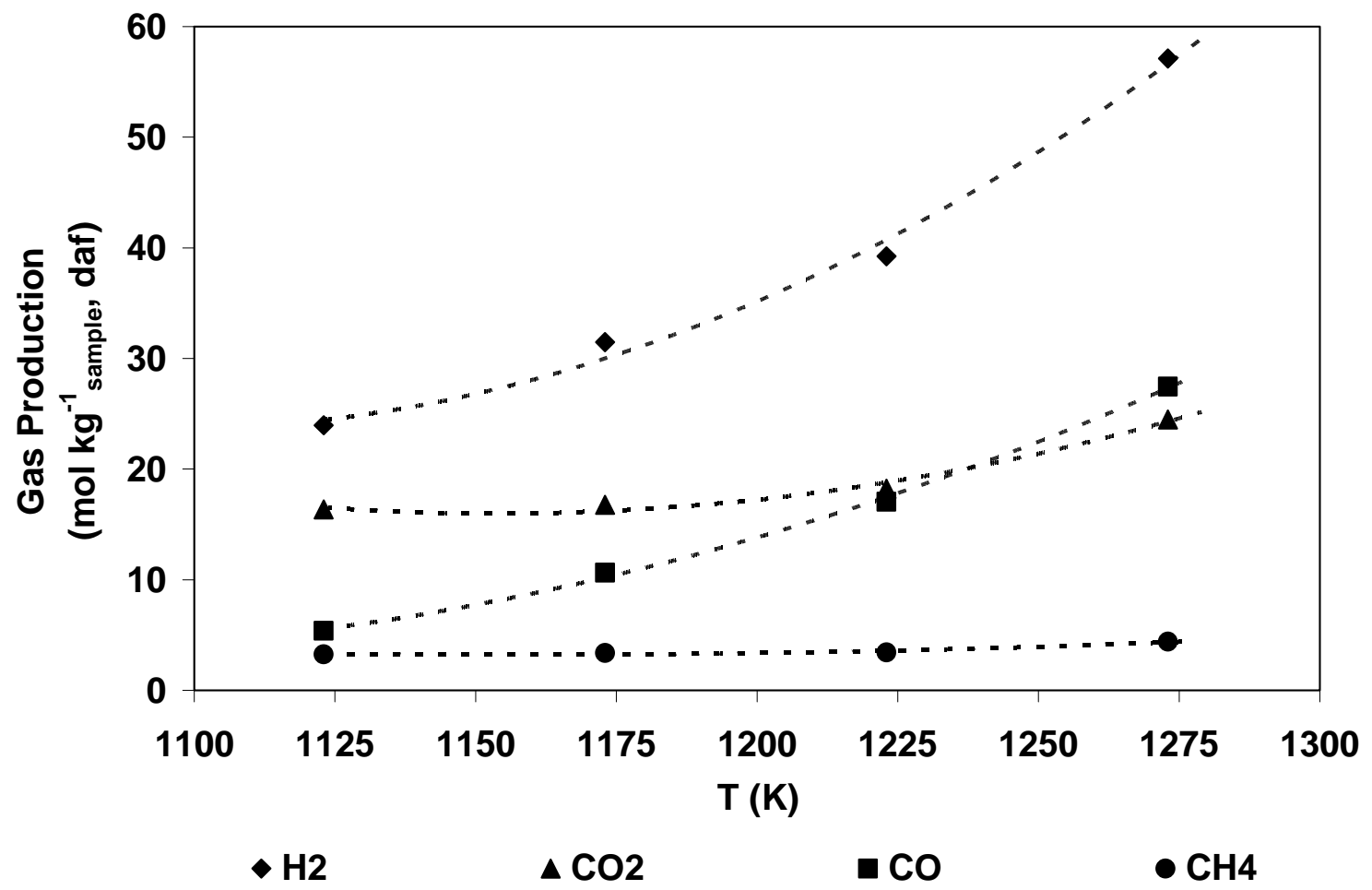

Figure 2. Effect of temperature on gas production during gasification of coal PT (1 MPa, $5 \%$ $\mathrm{O}_{2}, 70 \% \mathrm{H}_{2} \mathrm{O}$ ). 


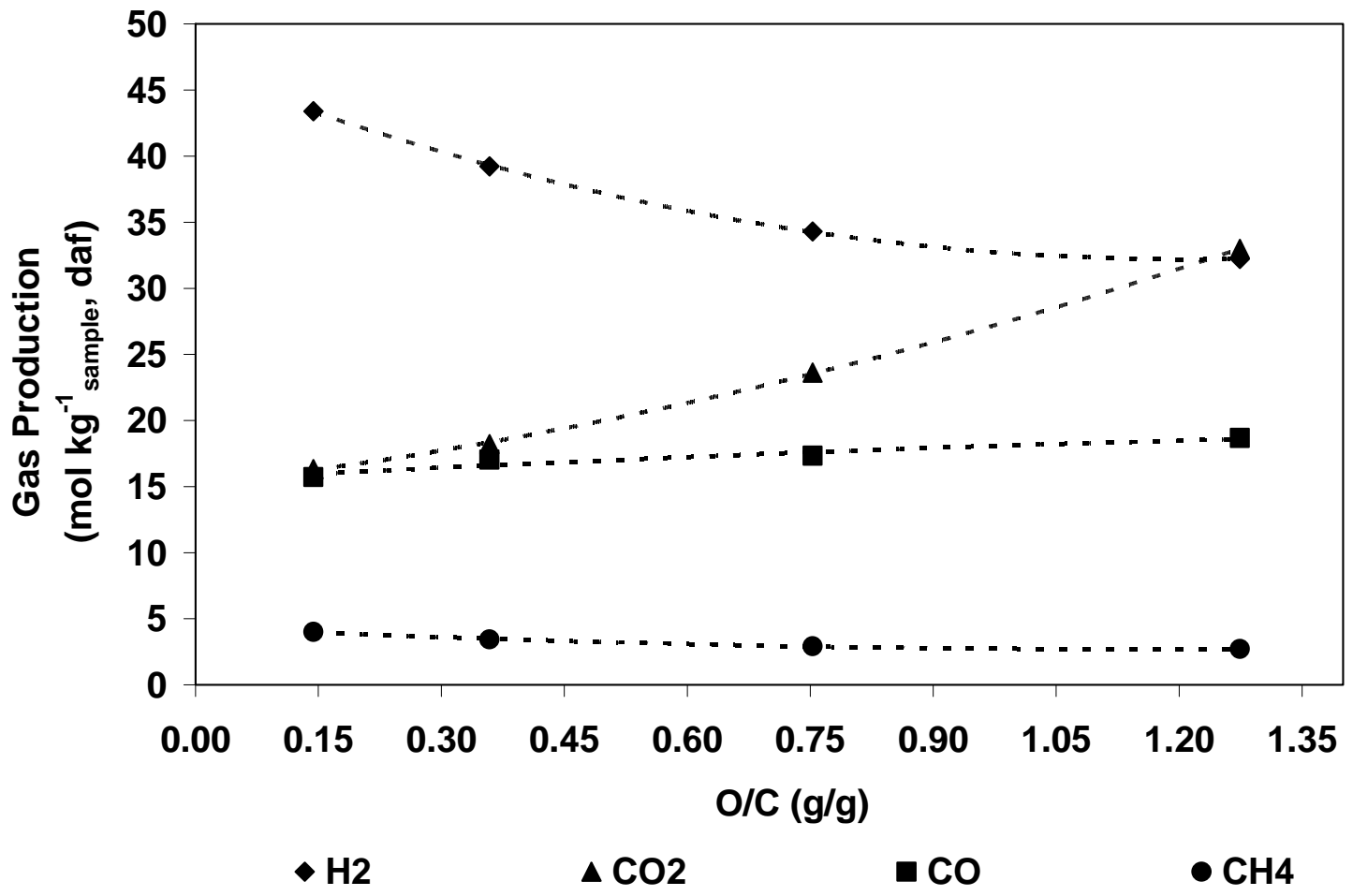

Figure 3. Effect of the $\mathrm{O} / \mathrm{C}$ ratio on gas production during gasification of coal PT (1 MPa, $1223 \mathrm{~K}, 70 \% \mathrm{H}_{2} \mathrm{O}$ ). 


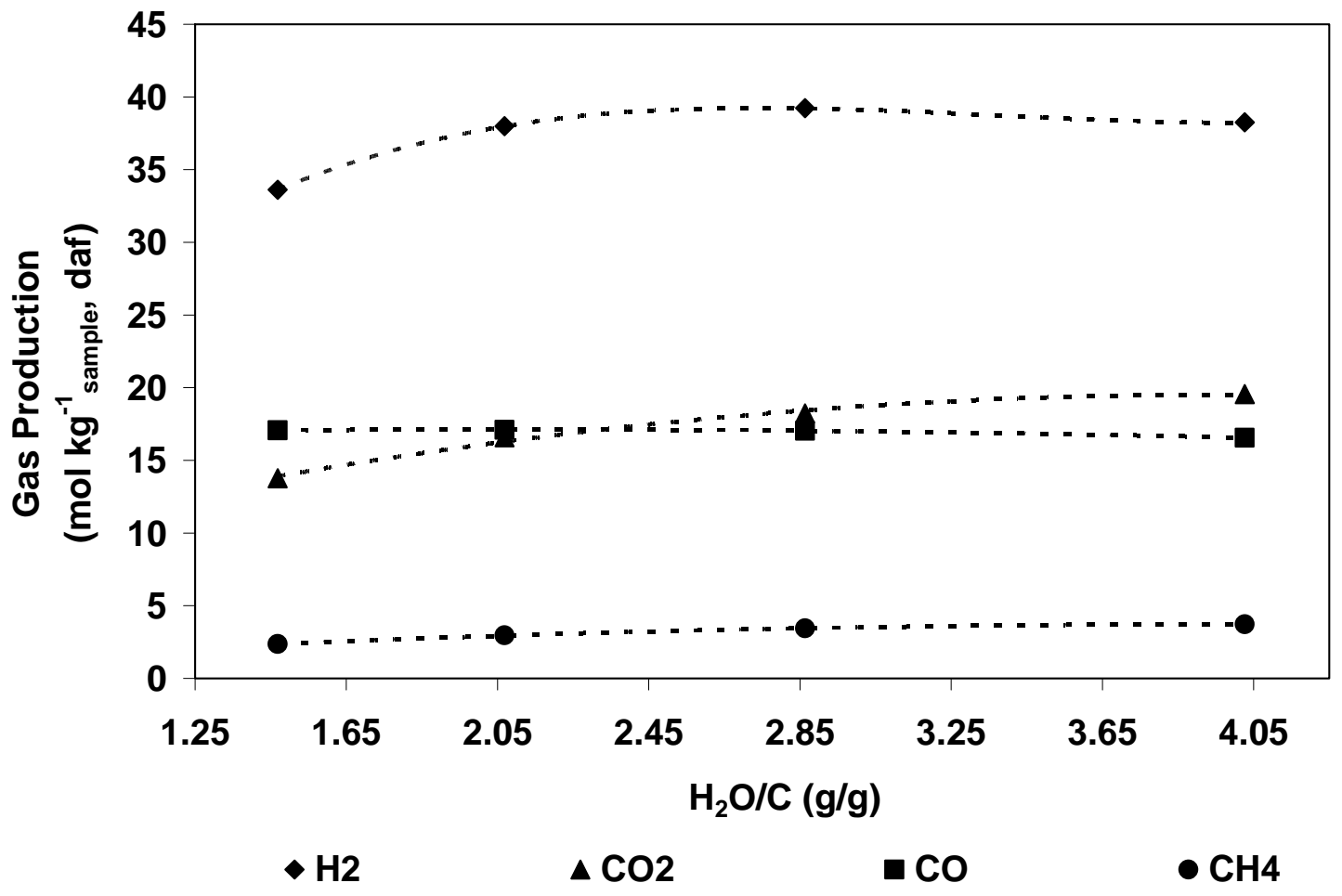

Figure 4. Effect of the $\mathrm{H}_{2} \mathrm{O} / \mathrm{C}$ ratio on gas production during gasification of coal PT (1 MPa, $1223 \mathrm{~K}, 5 \% \mathrm{O}_{2}$ ). 


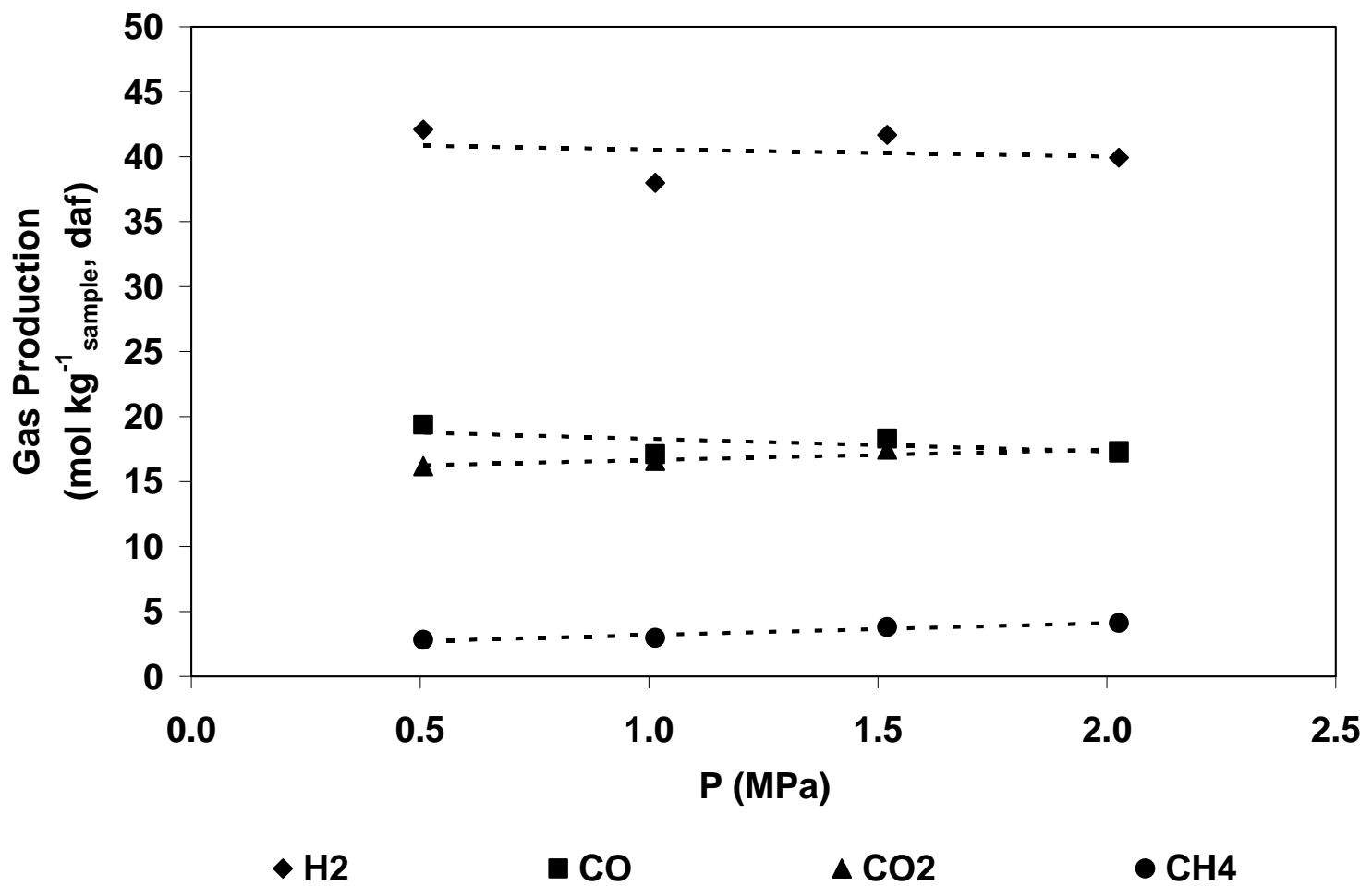

Figure 5. Effect of pressure on gas production during gasification of coal PT $\left(1223 \mathrm{~K}, 5 \% \mathrm{O}_{2}\right.$, $55 \% \mathrm{H}_{2} \mathrm{O}$ ). 


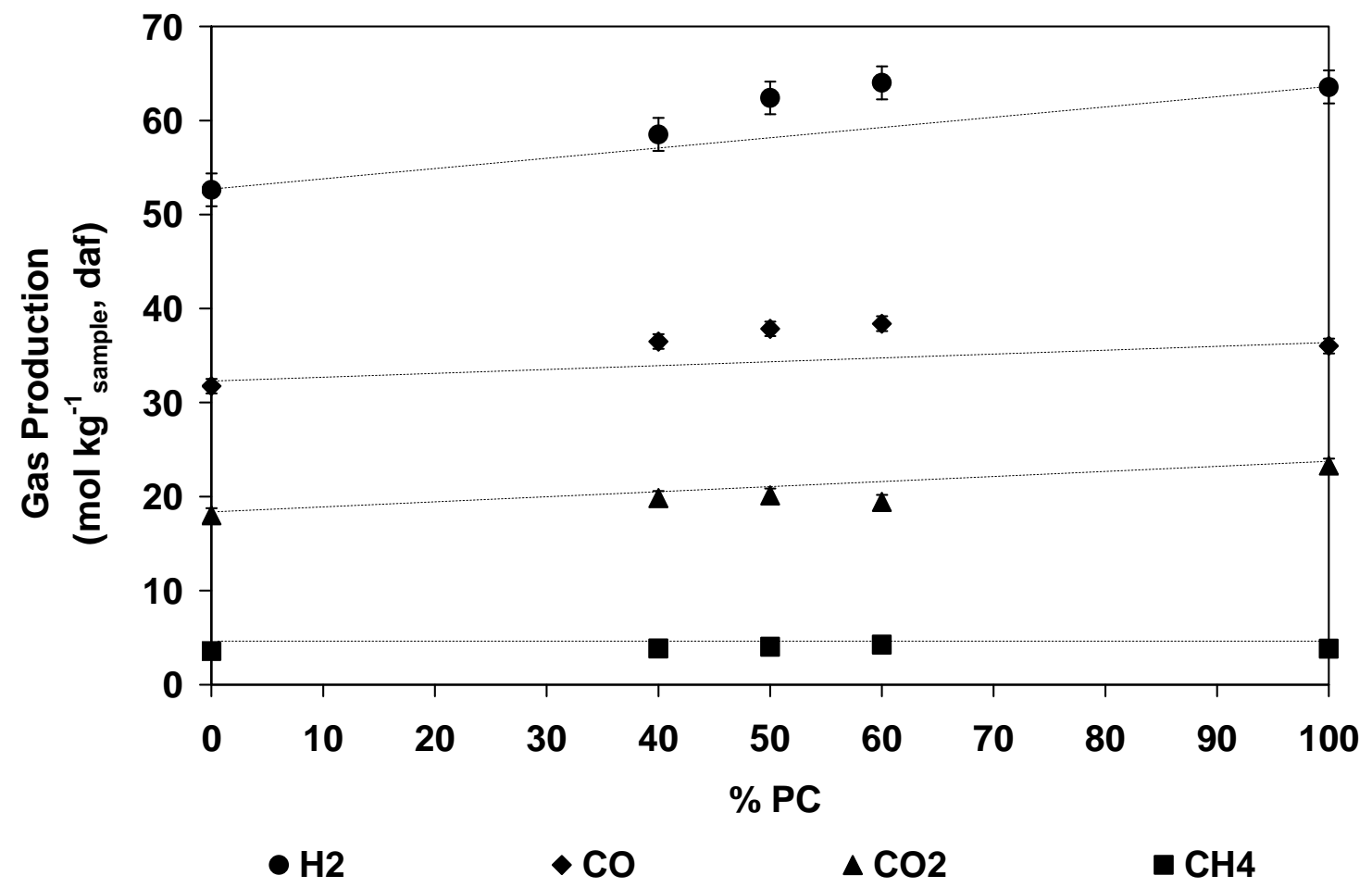

Figure 6. Gas production during gasification of PT-PC binary blends (1.5 MPa, $1273 \mathrm{~K}, 5 \%$ $\left.\mathrm{O}_{2}, 55 \% \mathrm{H}_{2} \mathrm{O}\right)$. 


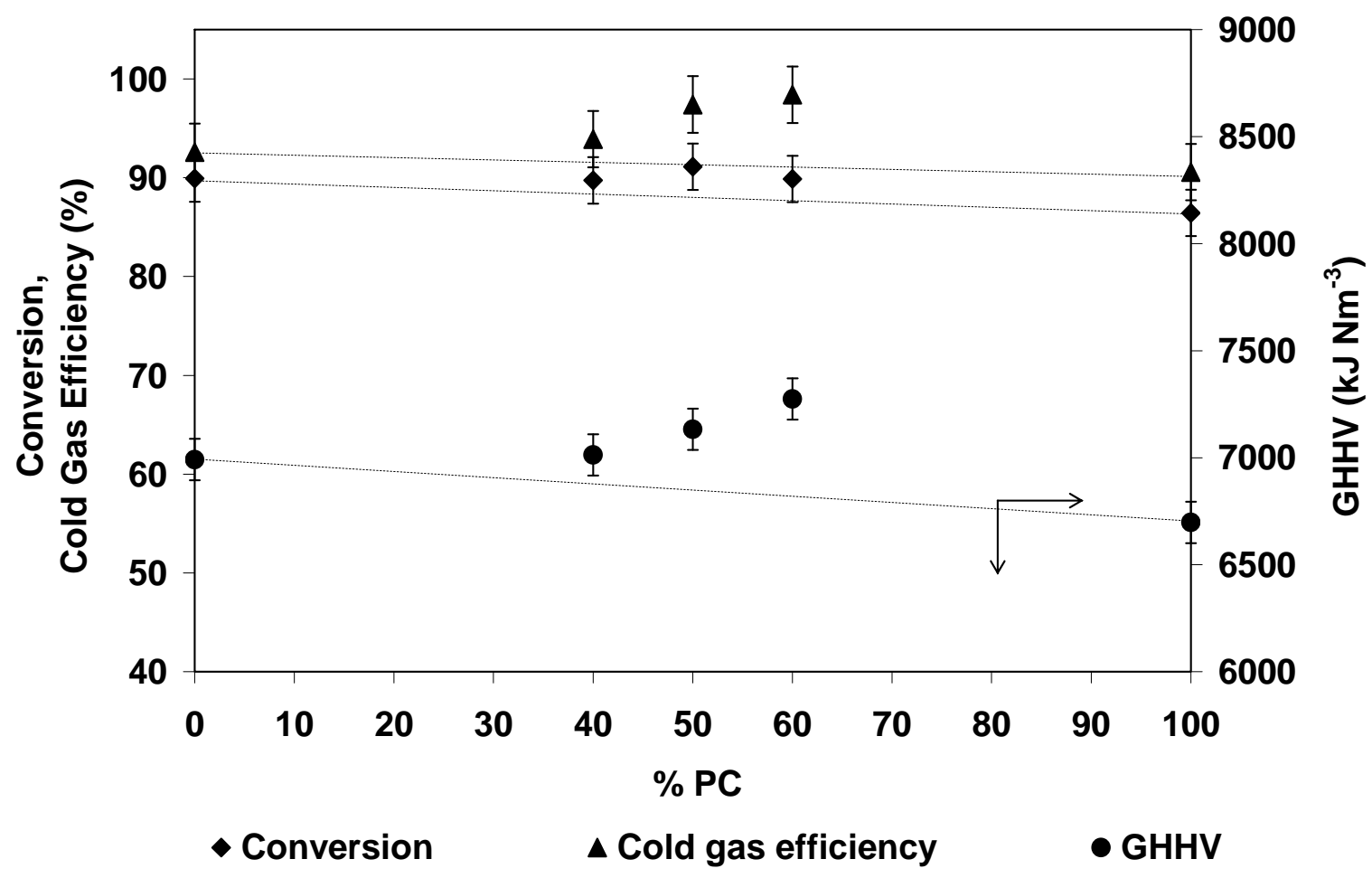

Figure 7. Carbon conversion, cold gas efficiency and high heating value obtained during cogasification of PT-PC binary blends (1.5 MPa, $\left.1273 \mathrm{~K}, 5 \% \mathrm{O}_{2}, 55 \% \mathrm{H}_{2} \mathrm{O}\right)$. 

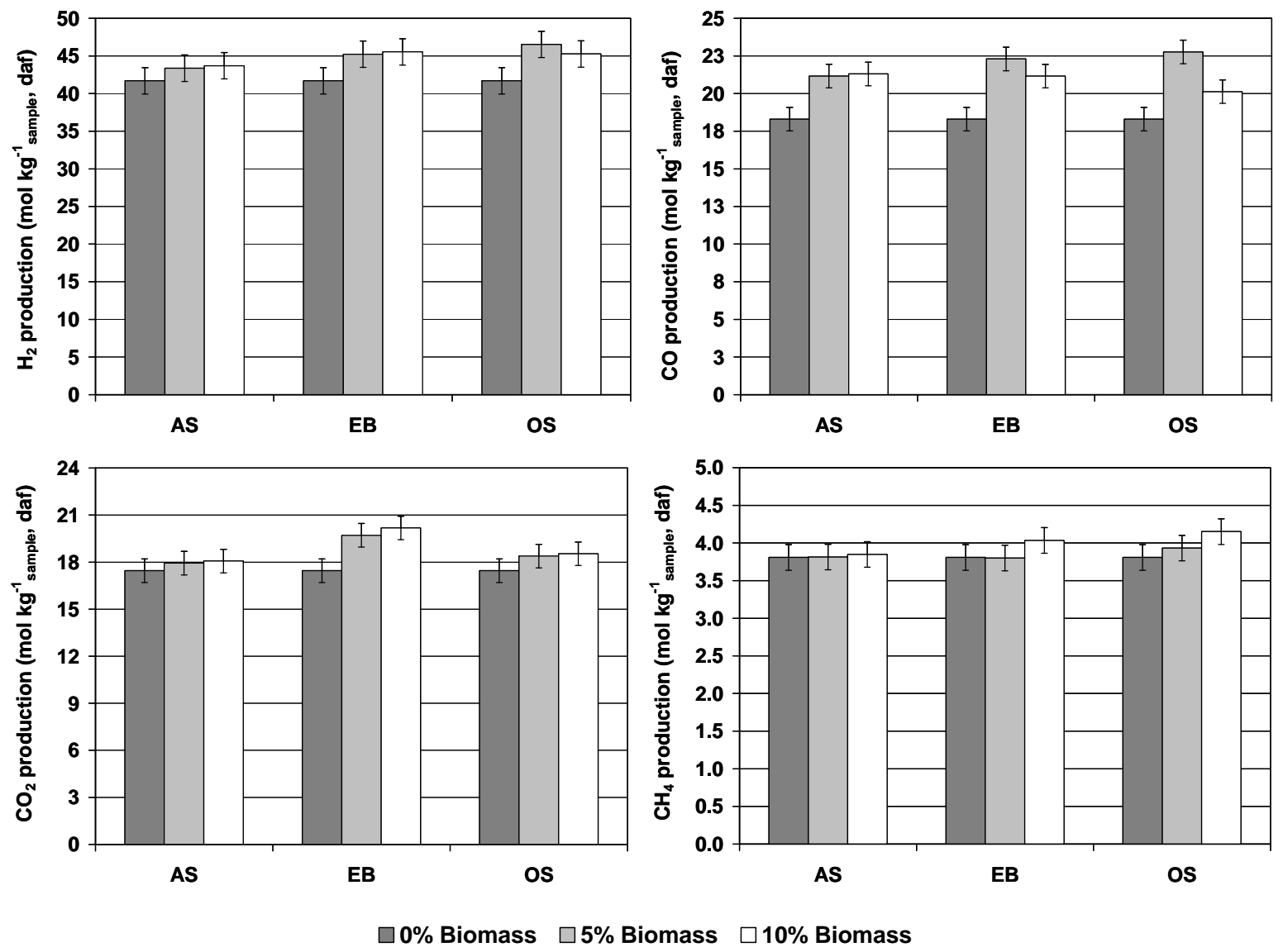

Figure 8. Gas production during co-gasification of binary blends of coal PT with biomass (1.5 $\left.\mathrm{MPa}, 1273 \mathrm{~K}, 5 \% \mathrm{O}_{2}, 55 \% \mathrm{H}_{2} \mathrm{O}\right)$. 


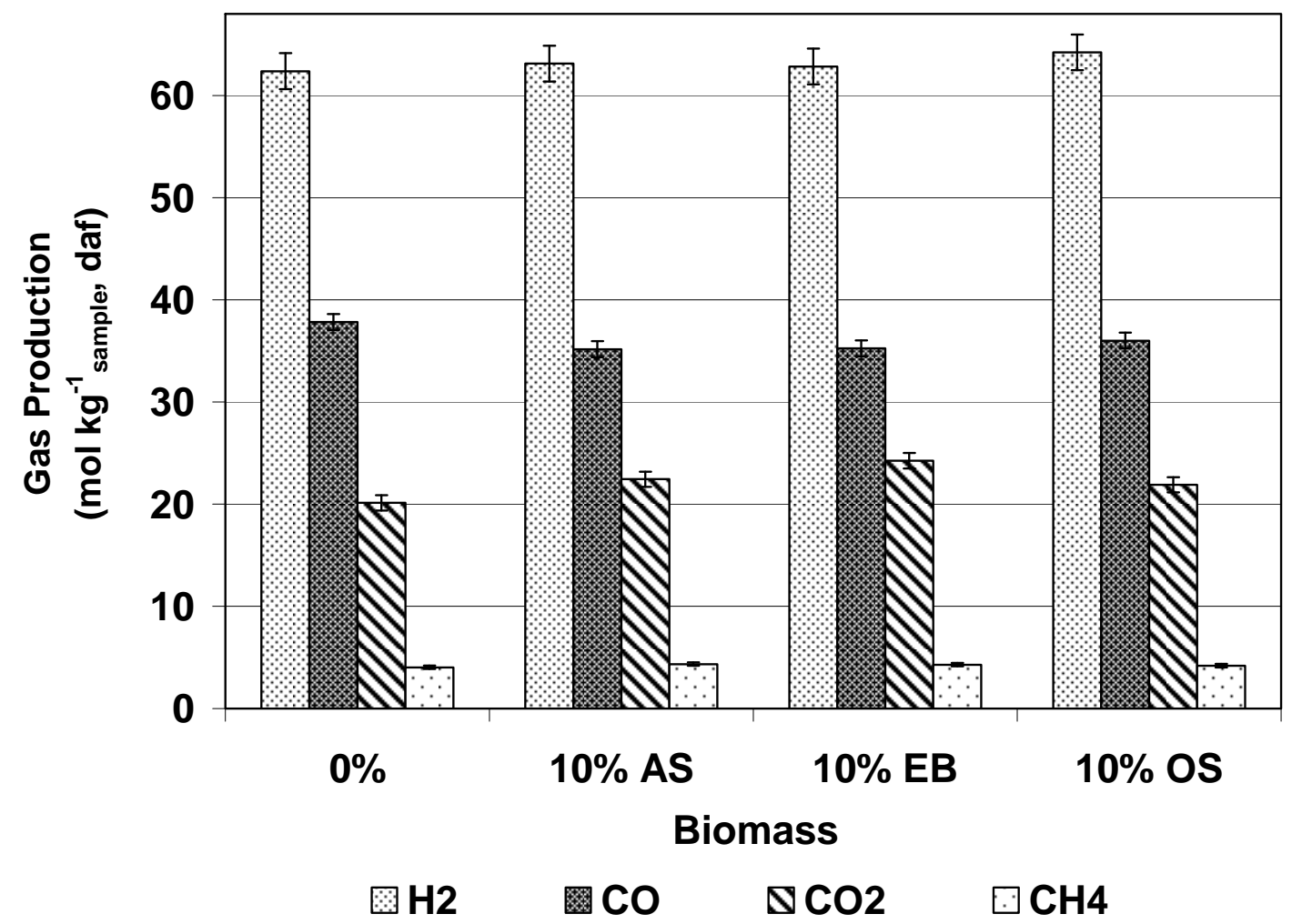

Figure 9. Gas production during co-gasification of ternary blends of PT-PC (45-45\%) with biomass (10\%) (1.5 MPa, $\left.1273 \mathrm{~K}, 5 \% \mathrm{O}_{2}, 55 \% \mathrm{H}_{2} \mathrm{O}\right)$. 